\title{
1 Modelling historical landscape changes
}

2

Lucy E. Ridding ${ }^{1 *}$, Adrian C. Newton ${ }^{2}$, John W. Redhead ${ }^{1}$, Stephen C. L. Watson ${ }^{2,3}$, Clare S. Rowland $^{4}$, James M. Bullock ${ }^{1}$

*Corresponding author: lucridd@ @eh.ac.uk, 01491692374, ORCID: 0000-0003-3141-8795

${ }^{1}$ UK Centre for Ecology \& Hydrology, Maclean Building, Benson Lane, Crowmarsh Gifford, Wallingford, Oxfordshire, OX10 8BB, UK

${ }^{2}$ Bournemouth University, Centre for Ecology, Environment and Sustainability, Faculty of Science and Technology, Talbot Campus, Poole, Dorset BH12 5BB, UK

${ }^{3}$ Current address: University of Portsmouth, School of Biological Sciences, Portsmouth Hampshire, PO1 2UP, UK

${ }^{4}$ UK Centre for Ecology \& Hydrology, Library Avenue, Lancaster, LA1 4AP, UK

\begin{abstract}
Context

Historical maps of land use/land cover (LULC) enable detection of landscape changes, and help to assess drivers and potential future trajectories. However, historical maps are often limited in their spatial and temporal coverage. There is a need to develop and test methods to improve re-construction of historical landscape change.
\end{abstract}

\section{Objectives}

To implement a modelling method to accurately identify key land use changes over a rural landscape at multiple time points.

\section{Methods}

We used existing LULC maps at two time points for 1930 and 2015, along with a habitat time-series dataset, to construct two new, modelled LULC maps for Dorset in 1950 and 1980 to produce a four-step time-series. We used the Integrated Valuation of Ecosystem Services and Tradeoffs (InVEST) Scenario Generator tool to model new LULC maps.

\section{Results}

The modelled 1950 and 1980 LULC maps were cross-validated against habitat survey data and demonstrated a high level of accuracy ( $87 \%$ and $84 \%$, respectively) and low levels of model uncertainty. The LULC time-series revealed the timing of LULC changes in detail, with the greatest losses in neutral and calcareous grassland having occurred by 1950, the period when arable land expanded the most, whilst the expansion in agriculturally-improved grassland was greatest over the period 1950-1980.

\section{Conclusions}

We show that the modelling approach is a viable methodology for re-constructing historical landscapes. The time-series output can be useful for assessing patterns and changes in the landscape, such as fragmentation and ecosystem service delivery, which is important for informing future land management and conservation strategies. 


\section{Keywords}

Agriculture; intensification; InVEST; LULC; mapping; time-series

\section{Acknowledgements}

Thanks to Maliko Tanguy and Emma Robinson, UKCEH Wallingford for their assistance with the UKCEH GEAR and CHESS datasets, respectively. Thank you to Josué Rodríguez, CEH Wallingford for his help installing python modules. Thank you also to James Douglass at the InVEST Natural Capital Project for his assistance with the Scenario Generator RuleBased tool. This work was funded by the Natural Environment Research Council (NERC), grant reference number: NE/P007716/1 as part of the project Mechanisms and Consequences of Tipping Points in Lowland Agricultural Landscapes (TPAL), which forms part of the Valuing Nature Programme. The Valuing Nature Programme (www.valuing-nature.net.) is funded by the Natural Environment Research Council (NERC), the Economic and Social Research Council, the Biotechnology and Biological Sciences Research Council, the Arts and Humanities Research Council and the Department for Environment, Food and Rural Affairs. The recast LCM1990 was supported by the NERC award number NE/R016429/1 as part of the UK-SCAPE programme delivering National Capability. 


\section{Introduction}

Land use/land cover (LULC) change is one of the main drivers of terrestrial biodiversity loss and altered ecosystem functions and services across the globe (Bateman et al., 2013; Tittensor et al., 2014). Anthropogenic LULC change is continuing to increase in extent and intensity (Marques et al., 2019) and is forecast to remain a major driver influencing terrestrial ecosystems in the future (Sala et al., 2000). Major changes in LULC include agricultural expansion and intensification, urbanisation, industrialisation, deforestation of natural forest and forest planting for timber, undertaken to meet the demands of an increasing population worldwide (Newbold et al., 2015; Song et al., 2018). While most studies focus on recent changes in land use, it is important to set current changes in a historical context (Cousins et al., 2015; Fescenko and Wohlgemuth, 2017). Some studies have examined such changes across networks of sample sites with known history (e.g. Redhead et al., 2014). However because this is restricted to specific locations, broader and complex patterns occurring across landscapes cannot be assessed. Re-constructing historical landscape maps allows LULC change to be examined across large areas, which is important for assessing the degree and type of changes and their spatial distribution. Such analyses can help inform land management decisions and support the implementation of future conservation measures, for example by identifying which areas are at greatest risk of future change.

LULC maps can be produced using a variety of sources, including field survey data, aerial photography and satellite imagery. Satellite images have become increasingly important for obtaining land cover data and are often used to monitor LULC change. Such data can also be used to support the development of LULC models, which aim to detect drivers of historical change and/or predict future changes (Veldkamp and Lambin, 2001). There are a wide variety of approaches used to model LULC change (Lu et al., 2004; Noszczyk, 2019). LULC models require the identification of the most important changes, such as urban expansion, agricultural intensification, or protection of natural areas, along with geographical predictors for where specific changes are most likely to occur. This may include soil type, topography, the previous LULC and other landscape features such as watercourses or infrastructure. As the importance of and demand for understanding LULC change has increased, a number of modelling software programmes have been developed (Fuchs et al., 2013; Sharp et al., 2016). These tools all employ a similar principle, whereby statistical analysis is used to identify patterns between the current distribution of LULC and environmental covariates.

Owing to data availability and time constraints, many LULC change studies are only able to re-construct one historical landscape. Comparisons in LULC are therefore often performed between two snapshots in time (Cousins et al., 2015; Hooftman and Bullock, 2012; Reis, 2008), which provides little information on the dynamics of change during the intervening period. More detailed information on trajectories of LULC change can help land managers and conservationists address more specific problems, which would otherwise be difficult to solve with only two time points. For example, determining where certain habitats occurred in the past and at what time period they were lost can be useful for locating areas where ecological restoration could take place or where habitats could be reconnected (Willems, 
2001). Similarly, variation in biodiversity among apparently similar habitats can be explained by their different land use histories, which can inform conservation management choices (Fescenko and Wohlgemuth, 2017).

Our study area is the county of Dorset, a predominantly rural landscape in southern England, which has undergone dramatic land use change, mostly through agricultural intensification, over the twentieth century (Hooftman and Bullock, 2012), in common with many regions across Europe. Dorset is an ideal area to examine LULC change, as there is a wealth of environmental datasets for this county, including an extensive botanical survey conducted by Good (1937). Good's dataset has provided valuable insights into patterns of change in heathland, calcareous grassland and woodland (Diaz et al., 2013; Keith et al., 2009; Newton et al., 2012) and more recently it has enabled the generation of a habitat time-series dataset across Dorset (Ridding et al., 2020). Ridding et al. (2020) determined the habitat type of over 3700 locations that were derived from the original Good survey sites, using contemporary field survey data and spatial datasets, for the years 1930, 1950, 1980, 1990 and 2015. Hooftman and Bullock (2012) created a land use map for Dorset in the 1930s and compared this with the UK Land Cover Map of 2000. They found that $97 \%$ of semi-natural grasslands were converted into agriculturally-improved grassland or arable land, as well as a large areas of heathlands and rough grassland. Although the study quantified broad LULC change over time, it was not possible to assess more accurately when these key LULC changes occurred. We aimed to improve on this by producing a time-series of maps spanning the past ca. 80 years in Dorset.

We used a modelling tool and detailed habitat data from Ridding et al. (2020) to inform the model, to generate LULC maps for Dorset in 1950 and 1980. These could then be used to analyse LULC change alongside the existing 1930s land cover map generated by Hooftman and Bullock (2012) and the CEH Land Cover Map 2015 (Rowland et al., 2017a). The aim of our study was to:

(i) Assess the accuracy of the modelling method;

(ii) Identify the timing of key LULC changes between 1930 and 2015;

(iii) Determine the uncertainty associated with the methodology.

\section{Method}

\subsection{Study Area}

Dorset, southern England, is currently ca. $2653 \mathrm{~km}^{2}$ in area, including the urban areas of Bournemouth, Poole and Christchurch that were added in 1974. Prior to that Dorset was ca. $2500 \mathrm{~km}^{2}$ in area (Hooftman and Bullock, 2012). The population more than doubled between 1930 and 2017, from ca. 198,000 to ca. 424, 670 excluding the urban centres of Bournemouth and Poole (Office for National Statistics, 2017). Like many regions in Western Europe, Dorset underwent considerable land use change during the $20^{\text {th }}$ and early $21^{\text {st }}$ centuries, through agricultural intensification, afforestation and urbanisation, which led to significant 
losses of semi-natural habitats and fragmentation of remaining areas (Hooftman and Bullock, 2012; Webb, 1990).

\subsection{InVEST Scenario Generator}

To create LULC maps of Dorset in 1950 and 1980, we used the Integrated Valuation of Ecosystem Services and Tradeoffs (InVEST) Rule Based Scenario Generator tool (Sharp et al., 2016) (subsequently "InVEST"). The years 1950 and 1980 were selected based on the availability of detailed habitat data from Ridding et al. (2020), which was required to inform the model. InVEST uses a range of inputs as predictor variables to model land cover change using multi-criteria evaluation methods and overlay analysis (Sharp et al., 2016). Although the model is relatively simple compared to other approaches (Liping et al., 2018; Verburg et al., 2002), it is ideal for modelling LULC change over large areas because it is computationally efficient. The simplicity of the model also makes it easy for the user to incorporate known drivers and constraints, compared to methods such as cellular automata and neural networks (Sharp et al., 2016).

InVEST determines the suitability of individual grid cells for LULC change based on the following inputs; a baseline raster LULC map, a transition matrix table and other optional data including land suitability factors, constraints and override layers (Fig. 1). The transition matrix table provides the quantity of change per LULC, and the likelihood of a particular LULC converting to another LULC. Within this table, LULC types are prioritised using a value between 1 and 9; thus when multiple objectives compete for a single cell, the one with the highest priority wins. A proximity value within the same table controls the assumption that pixels close to a LULC type are more likely to be converted to that cover type if they are suitable. The land suitability factors are physical and environmental variables that are likely to affect the suitability of land for a given LULC type and thus where in the landscape changes are likely to occur. The factors are given a factor weight between the value of 0 and 1, which determines the weight given to the factors vs. the transition matrix (Fig. 1). For example, a weight of 0.3 means that $30 \%$ of the final suitability is contributed by the factors, whilst the remaining $70 \%$ is attributed to the transition matrix (Sharp et al., 2016). The constraint input within InVEST prevents particular areas of the baseline landscape from changing where there are known factors that limit the likelihood of change. The override function, changes the LULC type of individual grid cells based on the users input, which occurs after the model has run. The following sections describe the data utilised for each model input.

\subsection{Baseline LULC maps}

The 1930 adapted Dudley Stamp Map produced by Hooftman and Bullock (2012) was used as the baseline LULC map for the creation of the 1950 Dorset map. The Dudley Stamp Map was created from the 1930s Land Utilisation Survey of Britain, where volunteers mapped LULC on six-inch to the mile Ordnance Survey (OS) maps (Stamp, 1931). This baseline map is based on the historic county boundary which we used for the entire map time-series to 
ensure consistency. The 1930 map did not clearly distinguish broadleaved from coniferous woodland. To address this issue we used Good's survey of 7575 vegetation stands (Good, 1937) to identify areas of coniferous woodland, which is likely to have been planted in this part of the country. The Good stands did not give complete coverage over Dorset, so all remaining patches of woodland which were not surveyed by Good were assumed to be broadleaved. This is likely to be an underestimate of coniferous woodland in Dorset; however records suggest that the coverage of coniferous woodland in southern England during this time was limited (Best and Coppock, 1962).

For the creation of the 1980 Dorset map, we used the CEH Land Cover Map 2015 (LCM2015) (Rowland et al., 2017a) as the baseline. The LCM2015 is a parcel-based land cover map for the UK created by classifying satellite data into 21 land classes that are based on the broad habitats defined by Jackson (2000). This method was preferred over using the generated 1950 map, since the LCM2015 is already a validated product, and this avoided using two sequential interpolations to create the 1980 map and the likely propagation of errors. We trialled the alternative approach in preliminary analyses but this gave less accurate results (see Online Resource 1). No acid grassland was identified in the LCM2015 in Dorset, even though this habitat was known to be present at this time (Ridding et al., 2020). This is because small areas of semi-natural habitat are often not detected in the LCM2015, which has a minimum mappable unit of 0.5 ha and is poor at detecting linear features, such as remnant strips of semi-natural grassland (Ridding et al., 2015). To address this and improve the accuracy of the baseline map, we replaced areas that were misclassified in the LCM2015 with acid grassland from Natural England's Priority Habitats' Inventory (Natural England, 2015) using ESRI ArcGIS v10.4 (@ ESRI, Redlands, CA).

The baseline maps and consequently the generated LULC time-series contained 12 aggregated land classes: "broadleaved woodland", "coniferous woodland", "arable", "calcareous grassland”, "acid grassland”, "neutral grassland”, "improved grassland”, "fen, marsh, swamp", "heathland", “coastal”, "water”, "urban” and "other”. The other category includes inland rock, which was only mapped for 1980, since this LULC type only occurred in the LCM2015 and not in the adapted Dudley Stamp map for 1930 (Hooftman and Bullock, 2012). The baseline maps were converted to $100 \mathrm{~m}$ resolution rasters, using a maximum area cell assignment in ArcGIS, and thus this resolution was also used to create the 1950 and 1980 map. The selected resolution, which has been used in other LULC studies (Moulds et al., 2018), was a compromise between capturing detailed LULC change, whilst maintaining a scale at which influential factors, such as soil and slope are likely to impact the InVEST predictions. At finer scales complex factors such as land ownership would likely become important and could not be captured by modelled factors in InVEST. Redhead et al. (2018) found that running the InVEST nutrient model at resolutions finer than $100 \mathrm{~m}$ showed only small gains in accuracy compared with the extra running time and large file sizes.

\subsection{Transition matrix}


To determine the amount of LULC change between 1930 and 1950, and between 2015 and 1980, and the likely transitions between different land covers, we utilised data from a survey time-series dataset where habitat type has been assessed at over 3700 sites across Dorset in 1930, 1950, 1980 and 2015 (see Ridding et al., 2020). Subsequently, we refer to this database as the "habitat time-series". The quantity of LULC change between both 1930 to 1950, and 2015 to 1980 was determined by calculating the percentage change in each LULC type, using the habitat time-series. A transition matrix of LULC change based on counts of changes across the habitat time-series sites was also generated for both time periods, which was subsequently adjusted on a scale of 0-10 to meet the input requirements for InVEST (see Online Resource $2 \& 3$ ). Where a particular LULC was not present in the original baseline data, for example improved grassland in 1930, an area change rather than a percentage change was required by InVEST. To calculate this we used the number of improved grassland sites in 1950 from the habitat time-series dataset, as a percentage of the total sites multiplied by the area of Dorset.

Priority values were required for LULCs which increased between 1930 and 1950; arable, coniferous woodland and urban. Priority values rank the LULC type, thus when multiple objectives compete for a single cell, the LULC with the highest priority wins. The literature reveals that there were considerable increases in arable and improved grassland during this period in Britain, and specifically in Dorset (Fuller, 1987; Hooftman and Bullock, 2012), suggesting that the transitions to these LULCs should be high priority in InVEST, thus we assigned scores of 8 and 7, respectively. During this time the planting of coniferous woodlands also increased rapidly (Best and Coppock, 1962), however farming was a higher priority in the British lowlands after the Second World War compared with conifer planting; thus we assigned a priority score of 5 to this LULC type.

For the 1980 map, the priority values were based on change in the opposite direction (2015 to 1980), thus the number of semi-natural habitats (neutral grassland, calcareous grassland, heathland, fen, marsh, swamp habitats) increased, as well as arable and coastal LULCs. The amount of arable land decreases between 1980 and 2015 (Ridding et al., 2020) due to technological advances improving productivity of existing arable land, hence from 2015 to 1980 arable land actually increases. Using the habitat time-series dataset from Ridding et al. (2020), we determined that increasing the number of semi-natural habitats was a greater priority than arable and coastal which only increased by a small percentage during the same period Ridding et al. (2020). Values of 9 and 7, were therefore assigned to semi-natural habitats and arable/coastal respectively. We used $1000 \mathrm{~m}$ as the proximity value (where cells close to a LULC type within this distance are more likely to be converted to that cover type if suitable) for the increasing habitats for both the 1950 and 1980 map, as any finer scales are likely to be influenced by more complex factors such as accessibility and land ownership as suggested by Redhead et al. (2020).

\subsection{Modelled factors}


We examined a range of physical and environmental suitability factors for the generation of both the 1950 and 1980 maps which is a requirement for InVEST, including slope, elevation, rainfall, temperature, soil and Agricultural Land Classification (AGL) (see Table 1). These factors were selected based on similar studies in the literature (Fuchs et al., 2013; Verburg and Overmars, 2009) and the availability of data for the whole of Dorset across multiple time periods where applicable (e.g. rainfall, temperature).

To determine which factors influenced the suitability of the increasing LULC types, we performed logistic regression using sites from the habitat time-series dataset (Ridding et al., 2020) that had remained versus sites which had undergone change for the 1950 and 1980 map. The sample size for habitat time-series sites converting to "urban" between 1930 and 1950 was too small to assess $(n=20)$ (noting the historical Dorset boundary excludes the large urban areas), and the same was true for coastal sites ( $n=17)$ between 2015 and 1980.

Elevation was strongly correlated with average temperature and rainfall (Pearson's $r>0.6$ or $<-0.6$ ), so this was excluded from all models. Logistic regression analyses were performed in R v.3.4.2 (R Core Team, 2019).

To determine the most suitable factor weight (factors vs transition matrix, see Fig. 1) we examined three different weights; $0.3,0.5,0.7$ and evaluated these using the habitat timeseries (see section on validation). A weight of 0.5 was selected to understand how equal weighting would perform, whilst 0.3 and 0.7 were arbitrarily selected using the example in Sharp et al. (2016), to represent and test the differences between a high or low weighting for factors versus transition matrix.

\subsection{Constraints and override}

In England the basic type of statutory protection is the designation as a Site of Special Scientific Interest (SSSI), which are areas of land selected for 'special interest by reason of any of its flora, fauna, or geological or physiographical features' (JNCC, 2015). Although the first SSSIs were not designated until the 1950s (DEFRA, 2009), Ridding et al. (2020) found sites which were classified as protected in the habitat time-series were more likely to remain as their original habitat. For this reason we used the extent of SSSI as a constraints layer. To improve the predicted output further, we also evaluated which $100 \mathrm{~m}$ cells had remained consistent between 1930 and 1990 for the 1950 map and 2015 and 1950 for the 1980 map. The partial Land Cover Map 1990 covered 83\% of Dorset and was created using the same methodology used to make the LCM2015 (Rowland et al., 2017b). We assumed that where the LULC within the 100 m cell matched, in 1930 and 1990 for example, the LULC would have stayed the same in 1950, thus these matching cells were also used as a constraint layer, to prevent LULC change occurring in those locations.

For the generation of the 1980 map we also used the override layer in InVEST (Fig. 1). For this we examined which 100 m cells were consistent in both the generated 1950 map and the revised LCM1990 map (Rowland et al., 2017b), and presumed that this remained the same in 
1980. This data was used as an override rather than a constraint, since the LULC type within particular cells may have differed between 1990 and 2015.

\subsection{Accuracy}

To assess the accuracy of the 1950 and 1980 Dorset maps produced using InVEST, we created ten cross-validation datasets from the habitat time-series dataset. In each of the 10 datasets, $75 \%$ of the habitat time-series sites were randomly selected for the training dataset, whilst the remaining $25 \%$ were used as a test dataset. Since some of the habitat time-series data did not completely match the baseline 1930 and 2015 map (see Ridding et al., 2020), we ensured that the test dataset only contained habitat time-series sites where the LULC in the habitat sites matched the corresponding baseline map, to ensure a fair comparison in the following interpolated map. Each of the ten training datasets were used to determine the percentage change for each LULC type and the significant factors which influenced change, as described above. For each of the ten cross-validation datasets for 1950 and 1980, InVEST was run in Python 2.7.0 one hundred times to account for the random selection of cells for change when all suitability factors and transition likelihoods were equal. A final output for each of the ten cross-validation datasets, was created using the modal LULC type for each cell. Where cells had equal counts of two LULC types no modal LULC was identified, thus these cells remain as "No data". This occurrence was infrequent, occurring in a mean of just $0.5 \%$ of cells per model run (see Table 2). During the process of combining the one hundred rasters using the modal LULC for each cell, if a LULC type did not demonstrate change due to the large number of possible cells where the conversion could occur, meaning none of the changes were evident in the final modal map, we used the cross-validation dataset with the greatest accuracy and the most accurate run within this set to determine where the LULC change should take place.

To validate the output for each of the ten datasets, we compared the LULC from the 1950 and 1980 map outputs with the LULC assigned in the corresponding year in the habitat timeseries (Ridding et al., 2020) using the test datasets (i.e. the remaining 25\%). Accuracy was calculated as the percentage of habitat time-series sites which were consistent between the LULC type in Ridding et al. (2020) and the 1950/1980 LULC output from InVEST. In order to determine the Cohen's Kappa Index, which measures the inter-rate agreement between two datasets (McHugh, 2012), a single LULC type per site is required, so for sites containing multiple LULC types we assigned the LULC from the 1950/1980 InVEST output which had the largest coverage in area within the habitat site.

To produce the final 1950 and 1980 map output, we determined the modal LULC across the ten map outputs produced from the cross-validation datasets. For individual cells with no modal LULC type, we assigned the LULC to the cross-validation dataset output which performed the best, determined using the highest percentage agreement and Kappa Index values. The final 1950 and 1980 map output was validated and averaged across the ten test datasets. 
To map uncertainty associated with the model runs in InVEST, we calculated how many of the one hundred output rasters matched the final modal LULC for each cell, for each of the ten cross-validation datasets, following Redhead et al. (2020). An average certainty value for the whole study area was generated, excluding cells which were included as a constraint or override layer. This is because these cells were not allowed to change in InVEST, thus the one hundred output rasters would always match the final modal output, therefore biasing the overall certainty score. To map and determine uncertainty for the final 1950 and 1980 map output, we averaged across the ten datasets.

\section{Results}

\subsection{Accuracy}

The created 1950 and 1980 LULC maps (Fig. 2) showed a strong correspondence with the LULC from the habitat time-series dataset across all of the ten cross-validation model runs and also the final map output for each time point, as indicated by the accuracy values in Table 2. There were also high levels of agreement between the map output and validation dataset, evidenced by the Kappa Index (Table 2), where values between 0.80 and 0.9 indicate a strong level of agreement (McHugh, 2012). The lowest Kappa Index recorded overall (0.77), still suggests a good level of agreement between the two datasets. The accuracy and agreement was slightly higher for the final 1950 output compared with that for 1980.

Error matrices were also generated for each time point; 1950 and 1980 (Table 3). Many LULC types showed good agreement between the generated map output and the habitat timeseries in 1950, including "coastal", "fen, marsh and swamp" and "broadleaved woodland". However there was some confusion between semi-natural grasslands and arable/improved grassland. There was also confusion between improved grassland and arable, where more improved grassland sites were classified as arable in the generated 1950 LULC map. Similar patterns were shown in the error matrices for 1980, with LULC types such as "coastal", "heathland", "fen, marsh and swamp" and "broadleaved woodland", being fairly consistent between the two datasets. The classification of calcareous grassland was better for 1980 , however there was still confusion between neutral grassland, arable and improved grassland.

\subsection{Timing of LULC change between 1930 and 2015}

The landscape underwent significant changes between 1930 and 2015 (Fig. 2). In 1930 the landscape was dominated by semi-natural grasslands (ca. 155, 008 ha) compared with 2015 when Dorset was dominated by improved grassland and arable land (ca. 200, 547 ha) (Table 4). Arable land expanded the greatest by 1950 in a region running south-west to north-east in Dorset (Fig. 2). This area and time period also coincided with the greatest loss of calcareous grassland (-25,096 ha). The loss of neutral grassland which occupied much of the north and western area was also higher by 1950 (-57,413 ha). The largest increase in improved 
grassland however, occurred between 1950 and 1980. Acid grassland and heathland are located in the south-east of the region, but reduced dramatically in area by 2015, with the greatest change occurring by 1980 . This was largely due to expansion of coniferous woodland and urbanisation, as well as improved grassland.

\subsection{Modelled Factors}

A range of physical and environmental variables were found to have a significant influence on the suitability for LULC change between 1930 and 1950, and 2015 and 1980 (Table 5). Many of the variables, including slope, soil texture and soil fertility were consistently significant across all of the ten cross validation datasets, suggesting they were good predictors of where particular LULC should occur (Table 5). Some variables, including soil texture and fertility, showed no variation for certain LULC types, meaning certain values were strongly associated with particular LULC types. For instance, heathland was consistently found on acidic sandy soils. Consequently models could not converge, which provided a strong justification to include these variables as modelled factors in InVEST.

To determine the best factor weight for the modelled factors against the transition matrix for InVEST (Fig. 1), we ran InVEST one hundred times for the first cross-validation dataset using three different weightings $(0.3,0.5$ and 0.7$)$ and compared the output LULC map with LULC from the habitat time-series. We determined that a factor weight of 0.5 produced the most accurate results and the highest Kappa Index score (Accuracy: 88\%, Kappa Index: $0.84)$, compared with $0.3(87 \%, 0.82)$ and $0.7(79 \%, 0.71)$, thus this factor weight was used for remaining cross-validation datasets for the 1950 and 1980 output. A factor weight of 0.5 ensures an equal contribution from influential factors and the transition matrix.

\subsection{Uncertainty}

There was greater certainty across the 1980 cross-validation datasets and the final map output compared with 1950 (Table 2). However, datasets from both time periods demonstrated high levels of certainty associated with the InVEST model. In each of the certainty maps (Fig. 2), there were particular regions of uncertainty across Dorset, which overlapped to some degree in both time periods. Much of the uncertainty in the 1950 output was concentrated around the south and east of Dorset. There was some overlap in the southern region in the 1980 output, but this appeared to extend further north. Very few cells across all of the cross-validation datasets for 1950 and 1980 contained "No data" suggesting there were only a small number of cells where no modal LULC was identified (Table 2).

\section{Discussion}

\subsection{Accuracy}

The modelling method employed in this study demonstrated high levels of accuracy, with both the 1950 and 1980 LULC maps showing a strong correspondence with the habitat time- 
series dataset. Although this may be expected given that the rule transitions are based on that dataset, a number of other parameters were determined for InVEST, which were clearly effective in this study. This shows that with just a limited sample of habitat sites, this modelling method can predict and determine historical changes across a landscape.

A significant proportion of the mismatch between the map outputs and the habitat time-series occurred between arable and improved grassland. However, some confusion between these intensive agricultural LULC types might be expected, particularly when modelling from 2015 to 1980, since agricultural systems in the UK often have grass and clover leys incorporated into arable rotations to manage weed problems or to increase soil fertility (AHDB, 2018) so the two classes are not necessarily mutually exclusive. This confusion could also be due to a number of social, economic and political issues that we could not model, including changes in pricing and profitability of crops vs. livestock (Zayed, 2016). There was also some confusion between some of the semi-natural grasslands and arable, particularly for the 1950 map output (Table 2), which is consistent with other historical land cover modelling (e.g. Fuchs et al., 2013). This highlights the difficulty in predicting such change and is likely to arise because other small scale factors which cannot be captured by InVEST, will also be influencing change, such as land ownership.

Despite the strong correspondence between map outputs and the habitat time-series, some LULC types which are known to have undergone considerable change between 1930 and 1950, changed by very little or not at all e.g. acid grassland (Table 4). Little heathland was converted in the 1950 map output, but it is known that this habitat experienced dramatic declines across Dorset over that time period (Moore, 1962; Webb and Haskins, 1980). This is likely to be due to the fact that large areas of heathland were lost to coniferous woodland during this period, which InVEST struggled to predict. This is because the area of coniferous woodland in 1930 was very small to begin with and the modelled factors only assisted in narrowing down the location of change to sandy acidic soils, which corresponded in general to the occurrence of heathland in Dorset, rather than narrowing down to specific $100 \mathrm{~m}$ cells within heathland areas. Fen, marsh and swamp and acid grassland were other LULC types which reduced by very little, if at all. This may be because these LULC types were competing with change from other LULC types such as calcareous and neutral grassland, which underwent significant conversion to improved grassland and arable and were a higher priority for change (Online Resource 4). This reflects one of the weaknesses of the InVEST tool, which currently models LULC change based on the percentage change of increasing LULC types only and not those which have shrunk.

Other issues arose due to differences with the baseline maps that were used to model the 1950 and 1980 outputs. For instance, the LULC type, "other", in this study referred to inland rock, which was classified in the 2015 map (Rowland et al., 2017a) and hence the generated 1980 output, but was absent from the 1930 and 1950 maps. There were also differences in how water was mapped, with rivers included in the 1930 baseline map, but not in 2015. The same was true for woodlands, with different classes for the baseline maps, which may explain why broadleaved woodland did not follow the trends identified in other studies (Hooftman and 
Bullock, 2012; Ridding et al., 2020). Furthermore, the definitions of LULC types varied slightly between the start and end maps for fen, marsh and swamp and coastal. For example, coastal in the 1930s map referred to sand dunes/littoral sediment, whilst in the 2015 map this included categories such as littoral rock, littoral sediment, supra-littoral rock and supralittoral sediment.

\subsection{Timing of LULC changes between 1930 and 2015}

The modelling method employed in this study has enabled us to identify the timing and spatial patterns of key LULC changes over ca. 85 year period. Overall, we found that $87 \%$ of semi-natural habitat was lost in Dorset, with the greatest losses occurring in neutral (99\%) and calcareous (97\%) grasslands. These results are consistent with other studies in Dorset (Hooftman and Bullock, 2012) and across England and Wales (Fuller, 1987; Ridding et al., 2015). By creating the time-series of LULC maps, we were able to determine that the greatest loss of calcareous and neutral grassland occurred in the period 1930-1950. This corresponds to the time where arable land increased most across Dorset, which is consistent with the period of agriculture intensification across Europe (Best and Coppock, 1962; Stoate et al., 2001). The time-series also enhanced findings from Ridding et al. (2020) by revealing where the changes occurred spatially; largely to the west of the county and along the fertile band of chalk soil running south-west to north-east. The largest increase in improved grassland occurred between 1950 and 1980. Arable land, however decreased after the 1950s. This most likely reflects the shift in farming, whereby fewer fields were required for conversion after advances in mechanisation and chemical applications led to great increases in yield (Stoate et al., 2001). There were also a number of economic and political factors, including falls in prices for agricultural products. Since a number of land covers, for example heathland, did not change by much between 1930 and 1950 using our modelling methodology, it was difficult to identify a more exact time period of loss, however the generation of the 1980 LULC map revealed that by this point there had already been a considerable loss of heathland.

\subsection{Uncertainty}

This study found low levels of uncertainty associated with the methodology, with an average of over $90 \%$ of the hundred runs matching with the final 1950 and 1980 map outputs. This means we have confidence in the modelled placement of the majority of LULC types, suggesting the modelled factors and transition tables were useful in narrowing down appropriate locations for certain LULC types to occur. This highlights the importance of having comprehensive data which can be used to inform InVEST, as the habitat time-series dataset (Ridding et al., 2020) did in our study. There was slightly greater certainty for the 1980 map compared with the 1950 map, which may reflect that more significant modelled factors were identified for changes from 2015 to 1980 compared with 1930 to 1950, giving InVEST more information and thus confidence in the placement of increasing LULC types. 
There were particular areas in Dorset that demonstrated higher levels of uncertainty, which were generally found around the southern and eastern areas of the region. There were areas of overlap along the southern coast towards the east on both the 1950 and 1980 maps. For 1950 this resulted in large amounts of arable land being predicted in these areas. It is likely that these areas were suitable for arable, including being flatter, having high soil fertility and a lower average temperature (significant modelled factors) and InVEST struggled to decide the exact $100 \mathrm{~m}$ x $100 \mathrm{~m}$ cells in which to position arable, so when the final modal map was created numerous arable cells were generated.

\section{Conclusion}

This study has shown that it is possible to generate a time-series of historical landscapes using a modelling method which involved the use of InVEST and detailed habitat time-series data to inform the model. To our knowledge this is the first time InVEST has been used reconstruct historical landscapes, rather than predict future scenarios (Gibson and Quinn, 2017; Sharma et al., 2018). We have shown that the method produced accurate outputs, but highlight the importance of obtaining appropriate data to inform the model. The creation of this LULC time-series allowed spatial and temporal changes in LULC to be identified over multiple time periods. This builds on Hooftman and Bullock (2012) by revealing more accurately the timing of change for certain LULC types, for instance the greatest losses in neutral and calcareous grassland occurred in 1950, the period when arable land expanded the most. We also determined a high level of certainty in using the modelling method employed in this study. This is important to assess, but is often overlooked in other LULC prediction studies (Sharma et al., 2018). Although the generated maps are not suitable for performing fine-scale analysis, particularly where high levels of uncertainty were detected, they are however useful for looking at more general patterns at the landscape scale, including habitat fragmentation and changes in ecosystem service delivery. This can be useful for environmental managers and landscape planners for informing future land management plans, as well as conservation strategies such as restoration. The modelling methodology can be used to create historical landscapes in any situation, providing there is sufficient data to inform the InVEST model.

This study however, has also highlighted some of limitations of reconstructing historical LULC maps, even when a region has abundant data, as in this study. This is particularly relevant for LULC types which cover a small area or those which have little information on environmental or physical factors which inform where a LULC type should occur. Increasing the availability of relevant data would improve such mapping approaches. This has also been identified in other studies (Liping et al., 2018; Sharma et al., 2018). For instance, increasing the availability of temporal datasets would be very beneficial for historical mapping, since most data are often static in time, such as accessibility and distance to roads. Furthermore, the indirect factors which are often very influential on LULC change, including political or economic drivers, such as the market for agricultural goods or the introduction of a new policies, are currently not incorporated due to model limitations. The incorporation of such 
610 factors into modelling programs such as InVEST and the associated effect on accuracy is 611 required.

612

613

614

615

616

617

618

619

620

621

622

623

624

625

626

627

628

629

630

631

632

633

634

635

636

637

638

639

640

641

642

643

644

645

646

647

648

649

650

651

652 
Table 1 A summary of variables used to model LULC change in Dorset between 1930 and 1950, and 2015 and 1980, with their source, scale/resolution and description

\begin{tabular}{|c|c|c|c|}
\hline Variable & Source & Scale & Description \\
\hline Elevation & $\begin{array}{l}\text { Digital Elevation Model } \\
\text { (Intermap Technologies, } \\
\text { 2007) }\end{array}$ & $5 \mathrm{~m}$ & Average elevation per $100 \mathrm{~m}$ grid square \\
\hline Slope & $\begin{array}{l}\text { Digital Elevation Model } \\
\text { (Intermap Technologies, } \\
\text { 2007) }\end{array}$ & $5 \mathrm{~m}$ & Average slope per $100 \mathrm{~m}$ grid square \\
\hline Average temperature & $\begin{array}{l}\text { CEH-CHESS (Robinson et } \\
\text { al., 2017) }\end{array}$ & $1 \mathrm{~km}$ & $\begin{array}{l}\text { Average temperature between } 1930 \text { and } 1950 \\
\text { (and } 1980 \text { and 2015) }\end{array}$ \\
\hline Temperature change & $\begin{array}{l}\text { CEH-CHESS (Robinson et } \\
\text { al., 2017) }\end{array}$ & $1 \mathrm{~km}$ & $\begin{array}{l}\text { Slope of temperature change between } 1930 \text { and } \\
1950 \text { (and } 1980 \text { and 2015) }\end{array}$ \\
\hline Average rainfall & $\begin{array}{l}\text { CEH-GEAR (Tanguy et al., } \\
\text { 2016) }\end{array}$ & $1 \mathrm{~km}$ & $\begin{array}{l}\text { Average rainfall between } 1930 \text { and } 1950 \text { (and } \\
1980 \text { and 2015) }\end{array}$ \\
\hline Rainfall change & $\begin{array}{l}\text { CEH-GEAR (Tanguy et al., } \\
\text { 2016) }\end{array}$ & $1 \mathrm{~km}$ & $\begin{array}{l}\text { Slope of rainfall change between } 1930 \text { and } 1950 \\
\text { (and } 1980 \text { and 2015) }\end{array}$ \\
\hline Soil Texture & $\begin{array}{l}\text { National Soilscape Map } \\
\text { (Cranfield University, } \\
\text { 2004) }\end{array}$ & $1: 250,000$ & $\begin{array}{l}\text { Five classes of soil texture; clayey, loamy, sandy, } \\
\text { peaty, } 0\end{array}$ \\
\hline Soil Fertility & $\begin{array}{l}\text { National Soilscape Map } \\
\text { (Cranfield University, } \\
\text { 2004) }\end{array}$ & $1: 250,000$ & $\begin{array}{l}\text { Seven classes of soil fertility, ranging from very } \\
\text { low to high. }\end{array}$ \\
\hline Soil Drainage & $\begin{array}{l}\text { National Soilscape Map } \\
\text { (Cranfield University, } \\
\text { 2004) }\end{array}$ & $1: 250,000$ & $\begin{array}{l}\text { Six classes of drainage, ranging from freely } \\
\text { draining to impeded draining }\end{array}$ \\
\hline $\begin{array}{l}\text { Agricultural Land } \\
\text { Classification (AGL) }\end{array}$ & (Natural England, 2012) & $1: 250,000$ & $\begin{array}{l}\text { Five classes which represent the quality of } \\
\text { farmland, ranging from excellent to very poor }\end{array}$ \\
\hline
\end{tabular}


Table 2 Accuracy, Kappa Index and certainty scores for each of the ten cross-validation datasets for the creation of the 1950 and 1980 LULC map for Dorset

\begin{tabular}{llllll}
\hline Year & $\begin{array}{l}\text { Cross-validation } \\
\text { dataset }\end{array}$ & Accuracy $(\%)$ & Kappa Index & $\begin{array}{l}\text { Average } \\
\text { certainty }\end{array}$ & \% of No Data \\
\hline 1950 & 1 & 88 & 0.84 & 89.83 & 0.19 \\
& 2 & 86 & 0.81 & 91.19 & 0.75 \\
& 3 & 88 & 0.83 & 90.41 & 1 \\
& 4 & 86 & 0.81 & 90.38 & 0.57 \\
& 5 & 88 & 0.83 & 89.83 & 2.03 \\
& 6 & 84 & 0.79 & 90.59 & 0.77 \\
& 7 & 88 & 0.84 & 90.73 & 0.93 \\
& 8 & 86 & 0.81 & 90.68 & 0.61 \\
& 9 & 89 & 0.85 & 90.31 & 0.77 \\
& 10 & 89 & 0.85 & 90.37 & 1.53 \\
& Final & 87 & 0.82 & 90.30 & 0 \\
\hline 1980 & 1 & 83 & 0.77 & 94.33 & 0.17 \\
& 2 & 86 & 0.82 & 95.32 & 0.17 \\
& 3 & 83 & 0.78 & 96.42 & 0.17 \\
& 4 & 85 & 0.80 & 94.39 & 0.17 \\
& 5 & 87 & 0.82 & 94.34 & 0.17 \\
& 6 & 86 & 0.81 & 94.40 & 0.17 \\
& 7 & 82 & 0.77 & 95.69 & 0.17 \\
& 8 & 82 & 0.77 & 97.23 & 0.17 \\
9 & 86 & 0.81 & 95.00 & 0.17 \\
& 10 & 84 & 0.79 & 95.30 & 0.17 \\
& Final & 84 & 0.78 & 95.24 & 0 \\
\hline
\end{tabular}


Table 3 Error matrices for (a) the final 1950 LULC map compared with the corresponding LULC from the habitat time-series (Ridding et al., 2020) and (b) the final 1980 LULC map compared with the corresponding LULC from the habitat time-series.

(a)

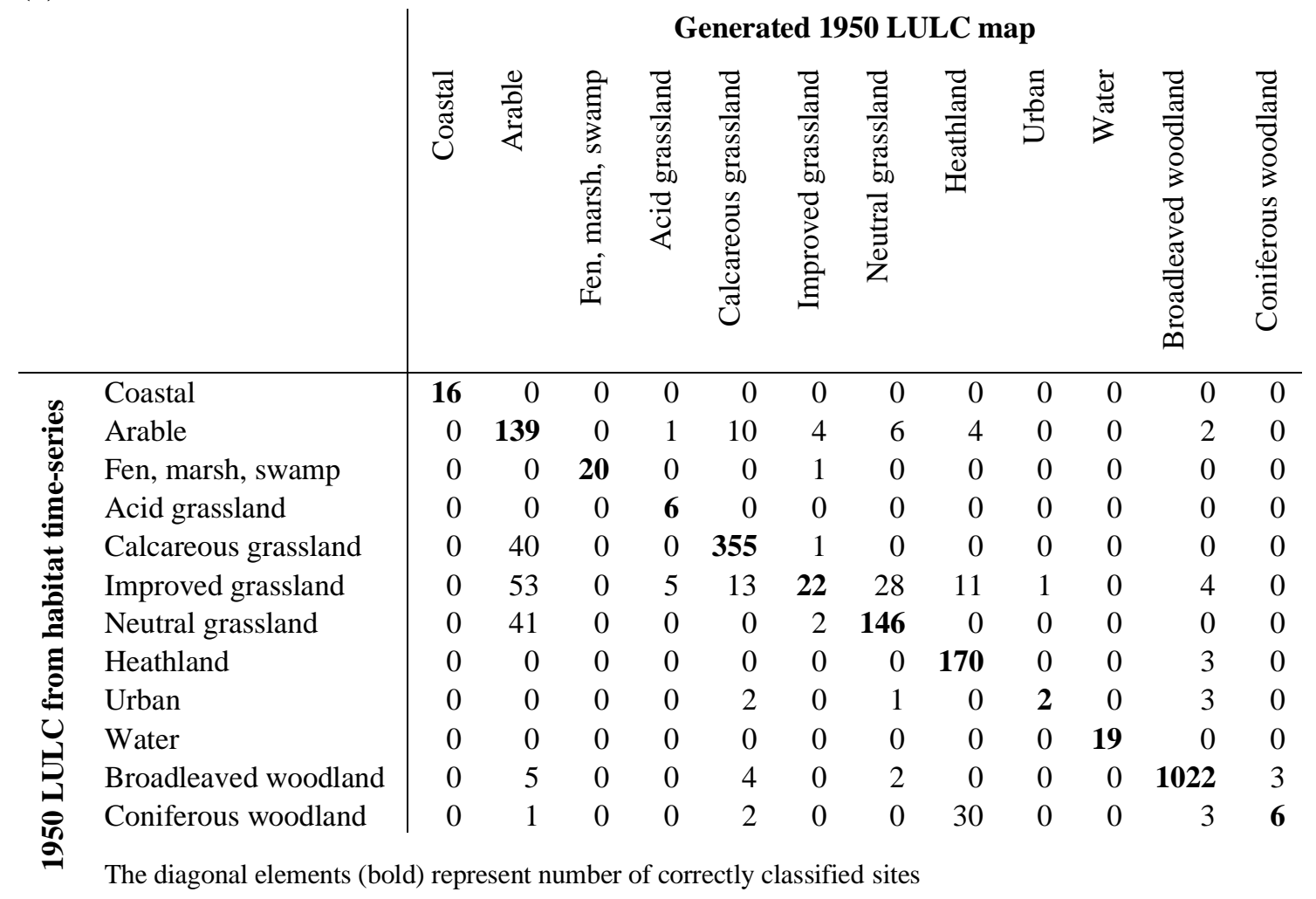

(b)

\begin{tabular}{|c|c|c|c|c|c|c|c|c|c|c|c|c|c|c|}
\hline & & \multicolumn{13}{|c|}{ Generated 1980 LULC map } \\
\hline & & 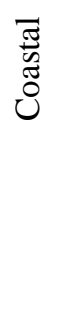 & $\frac{\frac{0}{0}}{\frac{\pi}{2}}$ & 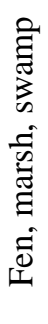 & 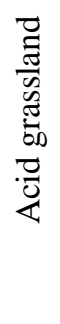 & 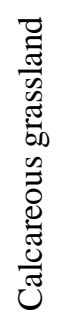 & 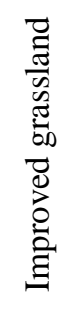 & 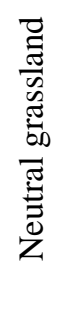 & 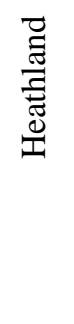 & 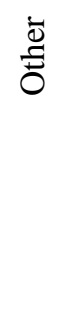 & 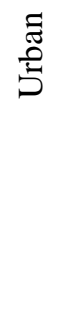 & 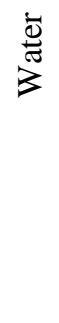 & 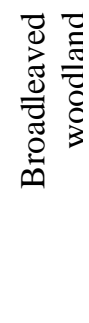 & 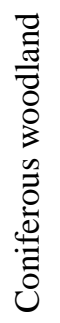 \\
\hline \multirow{13}{*}{ 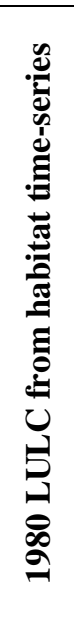 } & Coastal & 38 & 2 & 1 & 0 & 1 & 1 & 0 & 0 & 0 & 0 & 0 & 0 & 0 \\
\hline & Arable & 0 & 361 & 0 & 0 & 1 & 79 & 0 & 0 & 0 & 0 & 0 & 4 & 1 \\
\hline & Fen, marsh, swamp & 1 & 3 & 21 & 1 & 0 & 38 & 0 & 4 & 1 & 2 & 0 & 24 & 6 \\
\hline & Acid grassland & 0 & 1 & 0 & 2 & 0 & 4 & 0 & 1 & 0 & 0 & 0 & 0 & 0 \\
\hline & Calcareous grassland & 1 & 8 & 0 & 0 & 80 & 39 & 0 & 0 & 0 & 2 & 0 & 3 & 1 \\
\hline & Improved grassland & 0 & 53 & 0 & 1 & 4 & 522 & 1 & 1 & 0 & 0 & 0 & 3 & 0 \\
\hline & Neutral grassland & 2 & 8 & 0 & 0 & 0 & 42 & 5 & 1 & 0 & 0 & 0 & 4 & 0 \\
\hline & Heathland & 0 & 2 & 0 & 1 & 0 & 4 & 0 & 118 & 0 & 3 & 0 & 1 & 5 \\
\hline & Other & 0 & 0 & 0 & 0 & 0 & 0 & 0 & 0 & $\mathbf{0}$ & 0 & 0 & 0 & 0 \\
\hline & Urban & 0 & 0 & 0 & 0 & 0 & 1 & 0 & 0 & 0 & 10 & 0 & 0 & 0 \\
\hline & Water & 0 & 0 & 0 & 0 & 0 & 2 & 0 & 0 & 0 & 0 & 6 & 0 & 1 \\
\hline & Broadleaved & 0 & 16 & 1 & 0 & 2 & 24 & 0 & 0 & 0 & 0 & 0 & 892 & 0 \\
\hline & Coniferous woodland & 0 & 0 & 0 & 0 & 1 & 3 & 0 & 0 & 0 & 0 & 0 & 1 & 76 \\
\hline
\end{tabular}


The diagonal elements (bold) represent number of correctly classified sites

Table 4 Area (ha) of each LULC type in Dorset between 1930 and 2015.

\begin{tabular}{lrrrr}
\hline LULC & $\mathbf{1 9 3 0}$ & $\mathbf{1 9 5 0}$ & $\mathbf{1 9 8 0}$ & $\mathbf{2 0 1 5}$ \\
\hline Water & 1720 & 1762 & 651 & 665 \\
Arable & 44807 & 112443 & 86305 & 80426 \\
Neutral grassland & 101994 & 44202 & 946 & 672 \\
Calcareous grassland & 49022 & 23225 & 4331 & 1522 \\
Acid grassland & 4458 & 4458 & 412 & 422 \\
Fen, marsh, swamp & 478 & 476 & 489 & 605 \\
Improved grassland & 0 & 16104 & 111435 & 120121 \\
Heathland & 13912 & 13908 & 6091 & 5737 \\
Coastal & 460 & 460 & 1329 & 1222 \\
Urban & 14147 & 14288 & 14264 & 14396 \\
Broadleaved woodland & 20229 & 19132 & 16414 & 15822 \\
Coniferous woodland & 45 & 855 & 7477 & 8420 \\
Other & 0 & 0 & 703 & 814 \\
\hline
\end{tabular}


Table 5 Factors, their direction of change indicated by arrows $(\uparrow=$ increase, $\downarrow=$ decrease $)$ and significance $(* \mathrm{p}<$ $0.05, * * \mathrm{p}<0.01, * * * \mathrm{p}<0.001$ ), included in each of the ten-cross validation sites for (a) increasing the area of coniferous woodland, improved grassland and arable in 1950 compared to 1930, and (b) increasing the area of arable, neutral grassland, calcareous grassland, heathland, coastal and FMS (fen, marsh, swamp) habitats for 1980 compared to 2015. \# indicates model could not converge with these variables present, due to a large number of sites being allocated within the same category (these variables were thus included for use in InVEST).

(a) 1950 from 1930

\begin{tabular}{|c|c|c|c|c|c|c|c|c|c|c|c|}
\hline Habitat & Factors & 1 & 2 & 3 & 4 & 5 & 6 & 7 & 8 & 9 & 10 \\
\hline Coniferous & Rainfall change & $\downarrow * *$ & $\downarrow * *$ & $\downarrow * *$ & $\downarrow * * *$ & $\downarrow * * *$ & $\downarrow^{* *}$ & $\downarrow * * *$ & $\downarrow^{* *}$ & $\downarrow^{* *}$ & $\downarrow^{* * *}$ \\
\hline Coniferous & Temperature change & $\uparrow * *$ & $\uparrow * *$ & $\uparrow * *$ & & & $\uparrow * *$ & $\uparrow * *$ & $\uparrow * *$ & & \\
\hline Coniferous & Soil fertility & \# & $* * *$ & \# & $* * *$ & & \# & \# & \# & & \\
\hline Coniferous & Soil texture & \# & $* * *$ & $\#$ & & & \# & \# & \# & & \\
\hline Coniferous & Soil drainage & \# & $* * *$ & $\#$ & & & \# & \# & \# & & \\
\hline Improved & Temperature change & & & & & & & $\uparrow *$ & & & \\
\hline Improved & Slope & $\downarrow * *$ & $\downarrow * * *$ & $\downarrow * * *$ & $\downarrow * *$ & $\downarrow * * *$ & $\downarrow^{* *}$ & $\downarrow^{* *}$ & $\downarrow^{* *}$ & $\downarrow^{* *}$ & $\downarrow * *$ \\
\hline Arable & Slope & $\downarrow * * *$ & $\downarrow * * *$ & $\downarrow * * *$ & $\downarrow * * *$ & $\downarrow * * *$ & $\downarrow * * *$ & $\downarrow * * *$ & $\downarrow * * *$ & $\downarrow * * *$ & $\downarrow * * *$ \\
\hline Arable & Soil fertility & $* *$ & $* *$ & $* *$ & $* *$ & $* *$ & $* *$ & $* *$ & $* *$ & $* *$ & $* *$ \\
\hline Arable & Average temperature & $\downarrow * * *$ & $\downarrow^{*}$ & $\downarrow^{*}$ & $\downarrow * * *$ & $\downarrow^{* *}$ & $\downarrow * *$ & $\downarrow^{* *}$ & $\downarrow * * *$ & $\downarrow^{* *}$ & $\downarrow^{* *}$ \\
\hline
\end{tabular}

(b) 1980 from 2015

\begin{tabular}{|c|c|c|c|c|c|c|c|c|c|c|c|}
\hline Habitat & Factors & 1 & 2 & 3 & 4 & 5 & 6 & 7 & 8 & 9 & 10 \\
\hline Neutral & Soil drainage & \# & & & \# & & & & & & \\
\hline Neutral & Temperature change & $\downarrow^{*}$ & & & $\downarrow^{* *}$ & & $\downarrow^{*}$ & & & $\downarrow^{*}$ & \\
\hline Neutral & AGL & & & \# & & & & & & $\#$ & \\
\hline Neutral & Rainfall change & & & & $\uparrow *$ & & & & & & \\
\hline Neutral & Soil fertility & & & & & & & & \# & & \\
\hline Neutral & Soil texture & & & & & & & & \# & & \# \\
\hline Calcareous & Temp change & $\downarrow *$ & & $\downarrow^{*}$ & $\downarrow * *$ & & $\downarrow^{*}$ & $\downarrow^{*}$ & $\downarrow^{*}$ & $\downarrow *$ & $\downarrow^{* *}$ \\
\hline Calcareous & Slope & $\uparrow * *$ & $\uparrow^{*}$ & & & $\uparrow *$ & & & $\uparrow^{*}$ & & $\uparrow * *$ \\
\hline Calcareous & AGL & & & \# & & $\#$ & \# & & & \# & \\
\hline Calcareous & Rainfall change & & & & $\uparrow^{*}$ & & & & & & \\
\hline Calcareous & Soil fertility & & & & & & & & & & \\
\hline FMS & Slope & $\downarrow *$ & & & & & & & & $\downarrow *$ & $\downarrow *$ \\
\hline FMS & Soil texture & $* *$ & $* *$ & $* *$ & $* *$ & $* *$ & $* *$ & $* *$ & $* *$ & $* *$ & $* *$ \\
\hline
\end{tabular}




\begin{tabular}{|c|c|c|c|c|c|c|c|c|c|c|c|}
\hline FMS & Soil fertility & $* *$ & $* *$ & $* *$ & $* * *$ & $* *$ & $* *$ & & $* *$ & $* *$ & $* *$ \\
\hline FMS & Soil drainage & $\#$ & $\#$ & $\#$ & & $\#$ & & & $\#$ & & $\#$ \\
\hline FMS & Temperature change & $\downarrow * * *$ & $\downarrow^{* * *}$ & $\downarrow * *$ & $\downarrow^{*}$ & $\downarrow^{* *}$ & $\downarrow * * *$ & $\downarrow * * *$ & $\downarrow^{* *}$ & $\downarrow^{* *}$ & $\downarrow * * *$ \\
\hline FMS & Average temperature & $\uparrow^{*}$ & $\uparrow * * *$ & $\uparrow * * *$ & $\uparrow * * *$ & $\uparrow^{*}$ & $\uparrow^{* *}$ & & $\uparrow^{* *}$ & $\uparrow^{*}$ & $\uparrow^{*}$ \\
\hline FMS & Average rainfall & $\uparrow^{* *}$ & $\uparrow * *$ & $\uparrow * *$ & $\uparrow * * *$ & $\uparrow^{* *}$ & $\uparrow * *$ & $\uparrow * *$ & $\uparrow^{*}$ & $\uparrow * *$ & $\uparrow * *$ \\
\hline Arable & Slope & $\downarrow * * *$ & $\downarrow^{* * *}$ & $\downarrow * * *$ & $\downarrow * * *$ & $\downarrow * * *$ & $\downarrow^{* * *}$ & $\downarrow^{* * *}$ & $\downarrow * * *$ & $\downarrow * * *$ & $\downarrow * * *$ \\
\hline Arable & Temperature change & $\downarrow^{* *}$ & $\downarrow^{*}$ & & $\downarrow^{*}$ & & & & $\downarrow^{*}$ & $\downarrow^{*}$ & $\downarrow^{*}$ \\
\hline Arable & Soil fertility & & & $*$ & & $*$ & & & & $*$ & $* *$ \\
\hline Arable & AGL & & & & $*$ & & $*$ & & & & \\
\hline Arable & Average temperature & & & & & & & & & $\downarrow^{*}$ & \\
\hline Heathland & Soil drainage & $\#$ & $\#$ & $\#$ & $\#$ & $\#$ & $\#$ & \# & $\#$ & & $\#$ \\
\hline Heathland & Slope & $\downarrow^{*}$ & $\downarrow^{*}$ & $\downarrow^{*}$ & & $\downarrow^{*}$ & & $\downarrow^{*}$ & $\downarrow^{*}$ & $\downarrow^{*}$ & $\downarrow^{* *}$ \\
\hline Heathland & Soil fertility & $\#$ & $\#$ & $\#$ & $\#$ & $\#$ & $\#$ & $\#$ & $\#$ & $\#$ & $\#$ \\
\hline Heathland & Soil texture & \# & \# & \# & \# & \# & \# & \# & \# & \# & \# \\
\hline
\end{tabular}




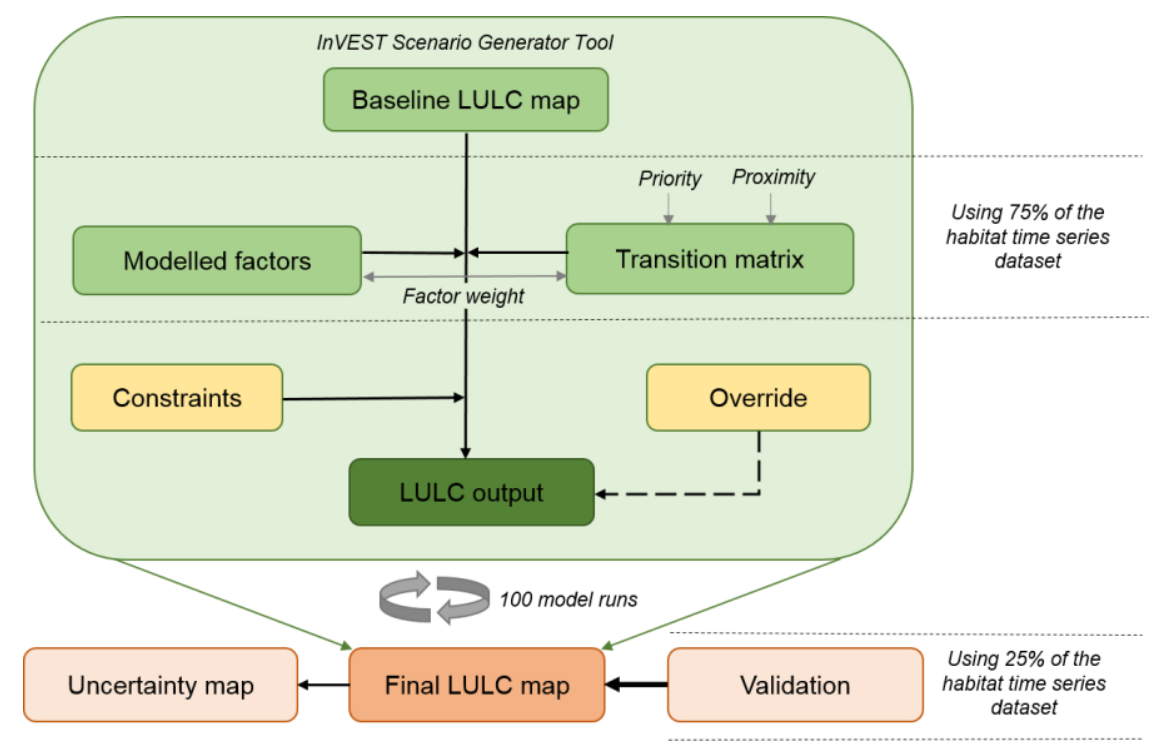

Fig. 1 Schematic showing the methodology used to create the 1950 and 1980 LULC maps of Dorset (adapted from Sharp et al. (2016)) 

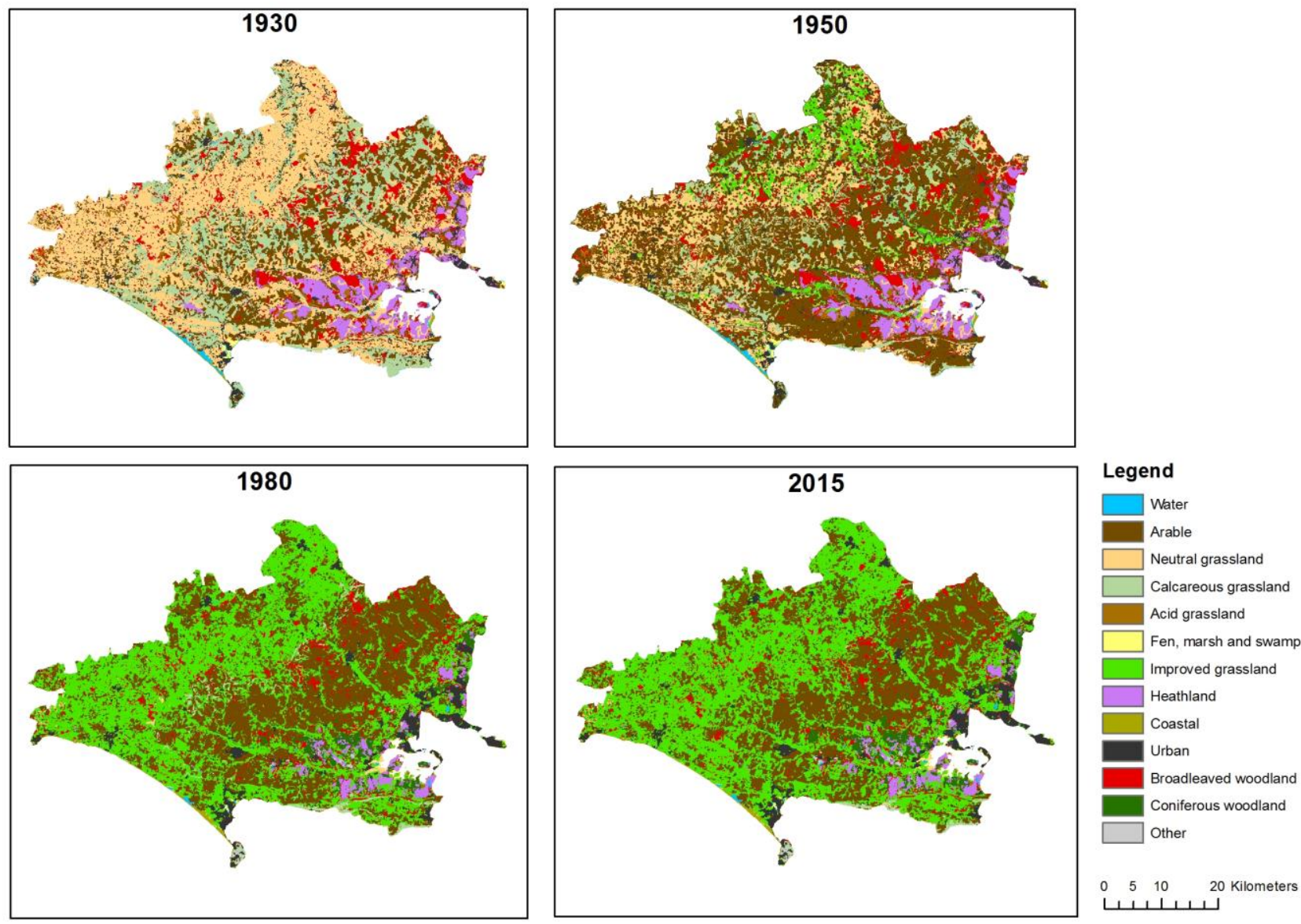

Fig. 2 LULC maps of Dorset indicating the 11 LULC types in 1930 (Hooftman and Bullock, 2012), 1950, 1980 and 2015 (Rowland et al., 2017a) 

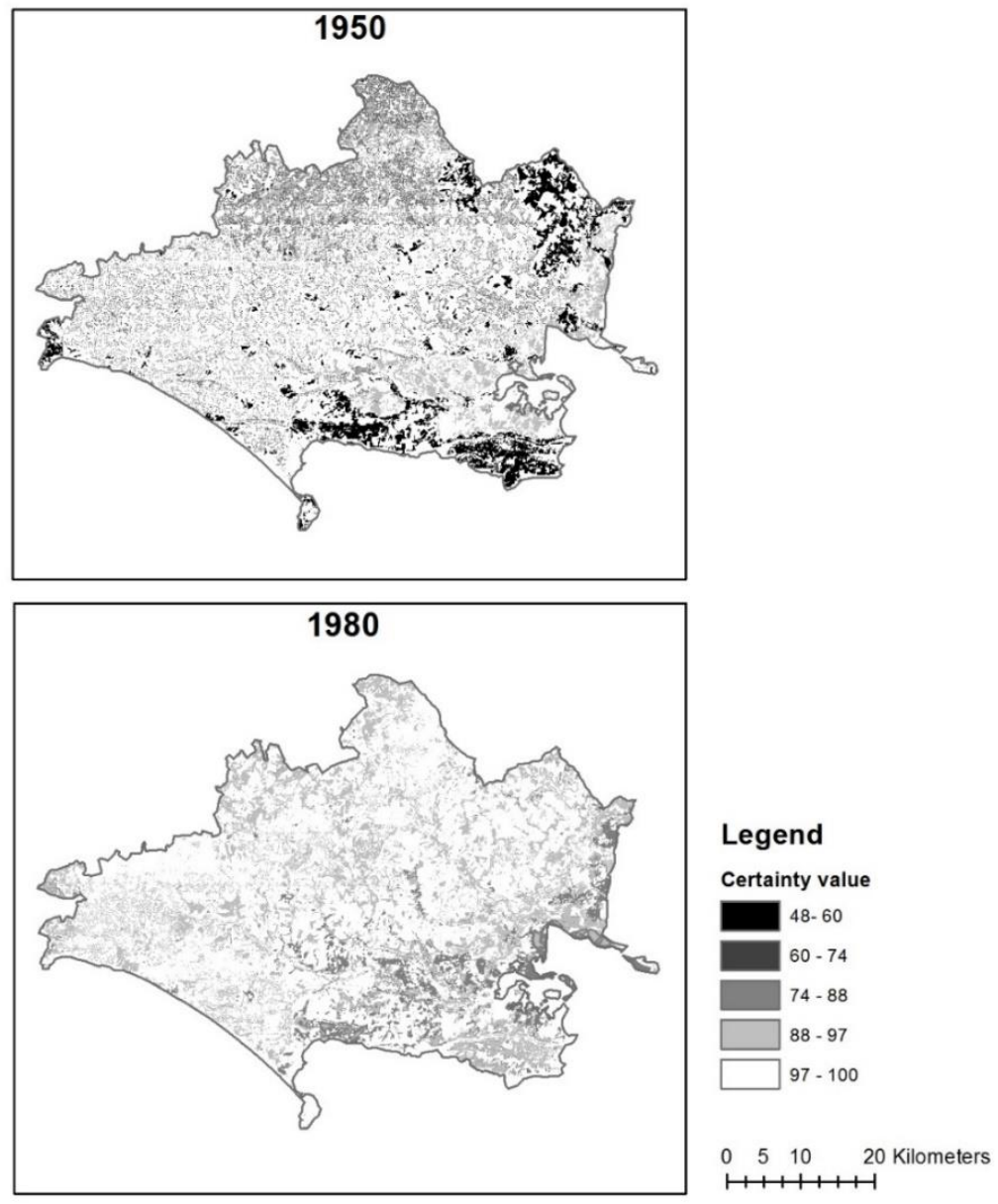

Fig. 3 Certainty maps of Dorset for 1950 and 1980, where light areas show good agreement between the hundred runs and the final modal map, whilst areas in black show greater uncertainty 


\section{References:}

AHDB, 2018. Livestock and the arable rotation. Warwickshire.

Bateman, I.J., Harwood, A.R., Mace, G.M., Watson, R.T., Abson, D.J., Andrews, B., Binner, A., Crowe, A., Day, B.H., Dugdale, S., Fezzi, C., Foden, J., Hadley, D., Haines-Young, R., Hulme, M., Kontoleon, A., Lovett, A.A., Munday, P., Pascual, U., Paterson, J., Perino, G., Sen, A., Siriwardena, G., van Soest, D., Termansen, M., 2013. Bringing Ecosystem Services into Economic Decision-Making: Land Use in the United Kingdom. Science (80-. ). 341, 45-50. https://doi.org/10.1126/science.1234379

Best, R., Coppock, J., 1962. The changing use of land in Britain. London.

Cousins, S.A.O., Auffret, A.G., Lindgren, J., Tränk, L., 2015. Regional-scale land-cover change during the 20th century and its consequences for biodiversity. Ambio 44, 17-27. https://doi.org/10.1007/s13280-014-0585-9

Cranfield University, 2004. National Soilscape Map.

DEFRA, 2009. ARCHIVE: SSSI legislative timeline [WWW Document]. URL http://webarchive.nationalarchives.gov.uk/20130402151656/http://archive.defra.gov.uk/r ural/protected/sssi/legislation.htm (accessed 4.7.15).

Diaz, A., Keith, S.A., Bullock, J.M., Hooftman, D.A.P., Newton, A.C., 2013. Conservation implications of long-term changes detected in a lowland heath plant metacommunity. Biol. Conserv. 167, 325-333. https://doi.org/10.1016/j.biocon.2013.08.018

Fescenko, A., Wohlgemuth, T., 2017. Spatio-temporal analyses of local biodiversity hotspots reveal the importance of historical land-use dynamics. Biodivers. Conserv. 26, 24012419. https://doi.org/10.1007/s10531-017-1366-0

Fuchs, R., Herold, M., Verburg, P.H., Clevers, J.G.P.W., 2013. A high-resolution and harmonized model approach for reconstructing and analysing historic land changes in Europe. Biogeosciences 10, 1543-1559. https://doi.org/10.5194/bg-10-1543-2013

Fuller, R.M., 1987. The changing extent and conservation interest of lowland grasslands in England and Wales: a review of grassland surveys 1930-1984. Biol. Conserv. 40, 281300.

Gibson, D., Quinn, J., 2017. Application of Anthromes to Frame Scenario Planning for Landscape-Scale Conservation Decision Making. Land 6, 1-17. https://doi.org/10.3390/land6020033

Good, R., 1937. An account of a botanical survey of Dorset. Proc. Linn. Soc. 149, 114-116.

Hooftman, D.A.P., Bullock, J.M., 2012. Mapping to inform conservation: A case study of changes in semi-natural habitats and their connectivity over 70 years. Biol. Conserv. 145, 30-38. https://doi.org/10.1016/j.biocon.2011.09.015

Intermap Technologies, 2007. NEXTMap British Digital Terrain Model Dataset Produced by Intermap. NERC Earth Observation Data Centre [WWW Document]. URL http://catalogue.ceda.ac.uk/uuid/8f6e1598372c058f07b0aeac2442366d. (accessed 10.17.16).

Jackson, D.L., 2000. Guidance on the interpretation of the Biodiversity Broad Habitat Classification (terrestrial and freshwater types): Definitions and the relationship with other classifications. JNCC Report 307.

JNCC, 2015. Guidelines for selection of biological SSSIs [WWW Document]. URL http://jncc.defra.gov.uk/page-2303 (accessed 4.7.15).

Keith, S.A., Newton, A.C., Morecroft, M.D., Bealey, C.E., Bullock, J.M., 2009. Taxonomic homogenization of woodland plant communities over 70 years. Proc. R. Soc. B Biol. Sci. 276, 3539-3544. https://doi.org/10.1098/rspb.2009.0938

Liping, C., Yujun, S., Saeed, S., 2018. Monitoring and predicting land use and land cover changes using remote sensing and GIS techniques-A case study of a hilly area, Jiangle, China. PLoS One 13, e0200493. https://doi.org/https://doi.org/10.1371/ 
journal.pone.0200493

Lu, D., Mausel, P., Brondizio, E., Moran, E., 2004. Change detection techniques. Int. J. Remote Sens. 25, 2365-2407. https://doi.org/10.1080/0143116031000139863

Marques, A., Martins, I.S., Kastner, T., Plutzar, C., Theurl, M.C., Eisenmenger, N., Huijbregts, M.A.J., Wood, R., Stadler, K., Bruckner, M., Canelas, J., Hilbers, J.P., Tukker, A., Erb, K., Pereira, H.M., 2019. Increasing impacts of land use on biodiversity and carbon sequestration driven by population and economic growth. Nat. Ecol. Evol. 3, 628-637. https://doi.org/10.1038/s41559-019-0824-3

McHugh, M., 2012. Interrater reliability: the kappa statistic. Biochem. Medica 22 (3), 276282.

Moore, N.., 1962. The Heaths of Dorset and their Conservation. J. Ecol. 50, 369-391.

Moulds, S., Buytaert, W., Mijic, A., 2018. Data Descriptor: A spatio-temporal land use and land cover reconstruction for India from 1960-2010. Sci. Data 5, 1-11. https://doi.org/10.1038/sdata.2018.159

Natural England, 2015. Priority Habitats' Inventory version 2.1 [WWW Document]. URL http://www.gis.naturalengland.org.uk/pubs/gis/gis_register.asp (accessed 1.6.18).

Natural England, 2012. Agricultural Land Classification, 1:250,000 [WWW Document].

Newbold, T., Hudson, L.N., Hill, S.L.L., Contu, S., Lysenko, I., Senior, R.A., Börger, L., Bennett, D.J., Choimes, A., Collen, B., others, 2015. Global effects of land use on local terrestrial biodiversity. Nature 520, 45.

Newton, A.C., Walls, R.M., Golicher, D., Keith, S.A., Diaz, A., Bullock, J.M., 2012. Structure, composition and dynamics of a calcareous grassland metacommunity over a 70-year interval. J. Ecol. 100, 196-209. https://doi.org/10.1111/j.1365-

2745.2011.01923.x

Noszczyk, T., 2019. A review of approaches to land use changes modeling. Hum. Ecol. Risk Assess. An Int. J. 25, 1377-1405.

Office for National Statistics, 2017. Mid-2017 Population Estimates [WWW Document]. URL

https://www.ons.gov.uk/peoplepopulationandcommunity/populationandmigration/popul ationestimates/bulletins/annualmidyearpopulationestimates/mid2017 (accessed 11.30.18).

R Core Team, 2019. R: A Language and Environment for Statistical Computing. R Foundation for Statistical Computing, Vienna, Austria.

Redhead, J.W., May, L., Oliver, T.H., Hamel, P., Sharp, R., Bullock, J.M., 2018. National scale evaluation of the InVEST nutrient retention model in the United Kingdom. Sci. Total Environ. 610-611, 666-677. https://doi.org/10.1016/j.scitotenv.2017.08.092

Redhead, J.W., Powney, G.D., Woodcock, B.A., Pywell, R.F., 2020. Effects of future agricultural change scenarios on beneficial insects. J. Environ. Manage. 265, 110550. https://doi.org/https://doi.org/10.1016/j.jenvman.2020.110550

Redhead, J.W., Sheail, J., Bullock, J.M., Ferreruela, A., Walker, K.J., Pywell, R.F., 2014. The natural regeneration of calcareous grassland at a landscape scale: 150 years of plant community re-assembly on Salisbury Plain, UK. Appl. Veg. Sci. 17, 408-418. https://doi.org/10.1111/avsc. 12076

Reis, S., 2008. Analyzing land use/land cover changes using remote sensing and GIS in Rize, North-East Turkey. Sensors 8, 6188-6202. https://doi.org/10.3390/s8106188

Ridding, L.E., Redhead, J.W., Pywell, R.F., 2015. Fate of semi-natural grassland in England between 1960 and 2013: A test of national conservation policy. Glob. Ecol. Conserv. 4, 516-525. https://doi.org/10.1016/j.gecco.2015.10.004

Ridding, L.E., Watson, S.C.L., Newton, A.C., Rowland, C.S., Bullock, J.M., 2020. Ongoing, but slowing, habitat loss in a rural landscape over 85 years. Landsc. Ecol. 35, 257-273. 
https://doi.org/https://doi.org/10.1007/s10980-019-00944-2

Robinson, E., Blyth, E., Clark, D., Comyn-Platt, E., Finch, J., Rudd, A., 2017. Climate hydrology and ecology research support system meteorology dataset for Great Britain (1961-2015) [CHESS-met] v1.2. https://doi.org/10.5285/b745e7b1-626c-4ccc-ac27$56582 \mathrm{e} 77 \mathrm{~b} 900$

Rowland, C.S., Morton, R.., Carrasco, L., McShane, G., O’Neil, A.W., Wood, C.M., 2017a. Land Cover Map 2015 (vector, GB), NERC Environmental Information Data Centre. https://doi.org/https://doi.org/10.5285/6c6c9203-7333-4d96-88ab-78925e7a4e73

Rowland, C.S., Morton, R.D., Carrasco, L., O’Neil, A., 2017b. Applying Earth Observation to assess UK land use change: Lot 2 Medium Resolution Optical, Report to BEIS, London.

Sala, O.E., Chapin III, F.S., Armesto, J.J., Berlow, E., Bloomfield, J., Dirzo, R., HuberSanwald, E., Huenneke, L.F., Jackson, R.B., Kinzig, A., Leemans, R., Lodge, D.M., Mooney, H.A., Oesterheld, M., Poff, L.N., Sykes, M.T., Walker, B.H., Walker, M., Wall, D.H., 2000. Global Biodiversity Scenarios for the Year 2100. Science (80-. ). 287, 1770-1774. https://doi.org/10.1126/science.287.5459.1770

Sharma, R., Nehren, U., Rahman, S., Meyer, M., Rimal, B., Aria Seta, G., Baral, H., 2018. Modeling Land Use and Land Cover Changes and Their Effects on Biodiversity in Central Kalimantan, Indonesia. Land 7, 57. https://doi.org/10.3390/land7020057

Sharp, R., Tallis, H.T., Ricketts, T., Guerry, A.D., Wood, S.A., Chaplin-Kramer, R., Nelson, E., Ennaanay, D., Wolny, S., Olwero, N., Vigerstol, K., Pennington, D., Mendoza, G., Aukema, J., Foster, J., Forrest, J., Cameron, D., Arkema, K., Lonsdorf, E., Kennedy, C., Verutes, G., Kim, C.K., Guannel, G., Papenfus, M., Toft, J., Marsik, M., Bernhardt, J., Griffin, R., Glowinski, K., Chaumont, N., Perelman, A., Lacayo, M., Mandle, L., Hamel, P., Vogl, A.L., Rogers, L., Bierbower, W., 2016. InVEST +VERSION+ User's Guide.

Song, X.-P., Hansen, M.C., Stehman, S. V, Potapov, P. V, Tyukavina, A., Vermote, E.F., Townshend, J.R., 2018. Global land change from 1982 to 2016. Nature 560, 639-643. https://doi.org/10.1038/s41586-018-0411-9

Stamp, D.., 1931. The Land Utilisation Survey of Britain. Geogr. J. 78, 40-47.

Stoate, C., Boatman, N.D., Borralho, R.J., Carvalho, C.R., De Snoo, G.R., Eden, P., 2001. Ecological impacts of arable intensification in Europe. J. Environ. Manage. 63, 337365. https://doi.org/10.1006/jema.2001.0473

Tanguy, M., Dixon, H., Prosdocimi, I., DG, M., Keller, V., 2016. Gridded estimates of daily and monthly areal rainfall for the United Kingdom (1890-2015) [CEH-GEAR]. https://doi.org/10.5285/33604ea0-c238-4488-813d-0ad9ab7c51ca

Tittensor, D.P., Walpole, M., Hill, S.L.L., Boyce, D.G., Britten, G.L., Burgess, N.D., Butchart, S.H.M., Leadley, P.W., Regan, E.C., Alkemade, R., Baumung, R., Bellard, C., Bouwman, L., Bowles-Newark, N.J., Chenery, A.M., Cheung, W.W.L., Christensen, V., Cooper, H.D., Crowther, A.R., Dixon, M.J.R., Galli, A., Gaveau, V., Gregory, R.D., Gutierrez, N.L., Hirsch, T.L., Höft, R., Januchowski-Hartley, S.R., Karmann, M., Krug, C.B., Leverington, F.J., Loh, J., Lojenga, R.K., Malsch, K., Marques, A., Morgan, D.H.W., Mumby, P.J., Newbold, T., Noonan-Mooney, K., Pagad, S.N., Parks, B.C., Pereira, H.M., Robertson, T., Rondinini, C., Santini, L., Scharlemann, J.P.W., Schindler, S., Sumaila, U.R., Teh, L.S.L., van Kolck, J., Visconti, P., Ye, Y., 2014. A mid-term analysis of progress toward international biodiversity targets. Science (80-. ). 346, 241244. https://doi.org/10.1126/science. 1257484

Veldkamp, A., Lambin, E.., 2001. Predicting Land-Use Change. Agric. Ecosyst. Environ. 85, 1-6. https://doi.org/10.3141/2119-16

Verburg, P.H., Overmars, K.P., 2009. Combining top-down and bottom-up dynamics in land 
use modeling: Exploring the future of abandoned farmlands in Europe with the DynaCLUE model. Landsc. Ecol. 24, 1167-1181. https://doi.org/10.1007/s10980-009-9355-7

Verburg, P.H., Soepboer, W., Veldkamp, A., Limpiada, R., Espaldon, V., Mastura, S.S.A., 2002. Modeling the spatial dynamics of regional land use: The CLUE-S model. Environ. Manage. 30, 391-405. https://doi.org/10.1007/s00267-002-2630-x

Webb, N.R., 1990. Changes on the Heathlands of Dorset, England, between 1978 and 1987. Biol. Conserv. 51, 273-286.

Webb, N.R., Haskins, L.E., 1980. An ecological survey of Heathlands in the Poole basin, Dorset, England, in 1978. Biol.Conserv. 17, 281-296. https://doi.org/doi: 10.1016/00063207(80)90028-2

Willems, J.H., 2001. Problems, approaches, and results in restoration of Dutch calcareous grassland during the last 30 years. Restor. Ecol. 9, 147-154. https://doi.org/10.1046/j.1526-100X.2001.009002147.x

Zayed, Y., 2016. Agriculture: historical statistics. House Commons Libr. 12, 1-18. 


\section{$\underline{\text { Online Resources }}$}

Online Resource 1 Justification of methodology for 1980 LULC map

To generate the 1980 LULC map for Dorset, we also modelled landscape change using the generated 1950 map as the baseline, rather than the Land Cover Map 2015 (LCM2015) (Rowland et al., 2017a). The same methodology of using the habitat time-series from Ridding et al. (2020) was employed to quantify the LULC change and generate the transition matrix, except this time we evaluated the change between 1950 and 1980, rather than 2015 to 1980. The LULCs which increased between 1950 and 1980 were consistent with the changes between 1930 and 1950, which included arable, improved grassland, coniferous woodland and urban. The same environmental factors (Table 1) were analysed using a logistic regression for the increasing LULCs, as described in the main text.

The resulting map output can be seen in Fig. S1a, alongside the 1980 map output produced using the LCM2015. The key difference between the 1980 output maps is the large difference in arable land that has been predicted from the two different baseline maps. To determine which map is likely to be the most accurate we used an alternative data source to validate the area of arable across Dorset in the 1980s. For this we used the Agriculture Census data which revealed the area of "total crops" in 1981 in $2 \mathrm{~km} \times 2 \mathrm{~km}$ grid squares (data obtained from http://edina.ac.uk/agcensus/, accessed 24/10/18). We calculated the area of arable in both of the 1980 maps using the same $2 \mathrm{~km}$ x $2 \mathrm{~km}$ grid squares. To determine which of the 1980 maps matched the Agricultural Census best, we compared histograms and examined the association between each map with the Agricultural Census data using Spearman's Rank Correlation. The histogram of the area of arable from the 1980 map created from LCM2015 (1980 from 2015) matches more closely with the Agricultural Census data compared with the 1980 map created from the 1950 (1980 from 1950) (Fig. S1b). The 1980 from 1950 histogram shows a more even frequency spread across the different areas, whilst the 1980 from 2015 shows a large proportion of $2 \mathrm{~km}$ x $2 \mathrm{~km}$ grid squares have smaller areas of arable, as in the Agriculture Census dataset. This is further confirmed by the stronger association detected between the 1980 from 2015 data and the Agricultural Census data $\left(R_{s}=0.66\right)$, compared with the 1980 from $1950\left(\mathrm{R}_{\mathrm{s}}=0.58\right)$ (Fig. S1c). 

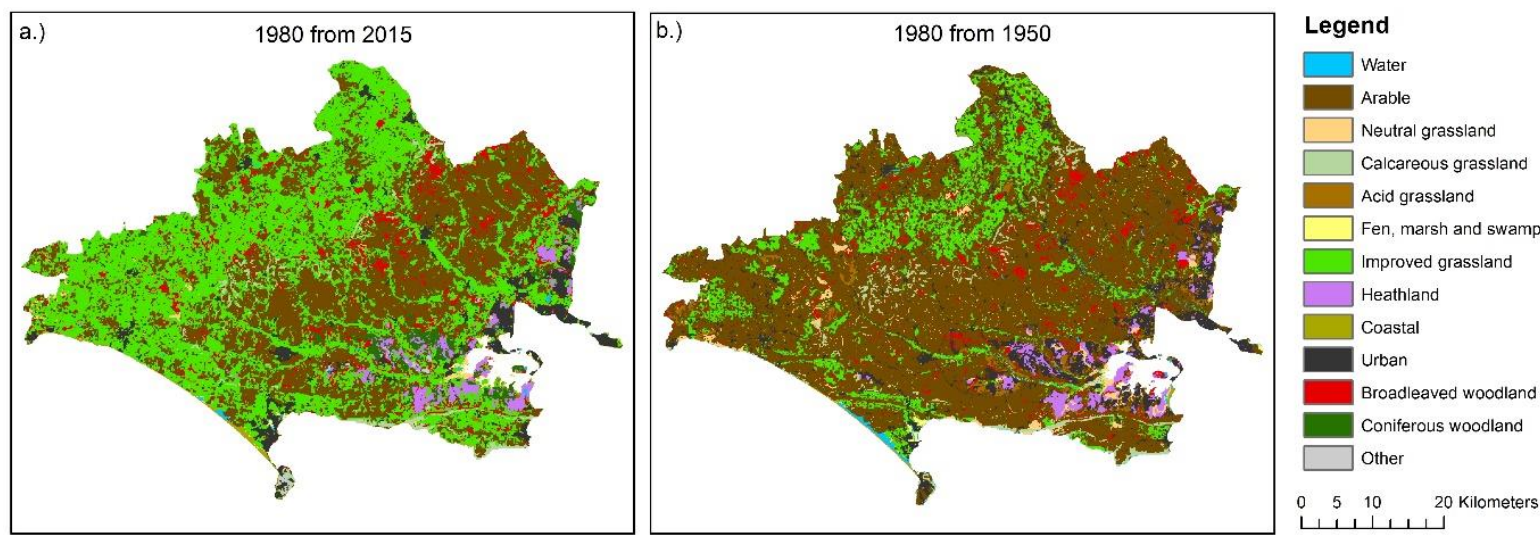

Fig. S1a Dorset LULC maps for 1980 created from a.) the Land Cover Map 2015 (Rowland et al., 2017a) and b.) the modelled 1950 map
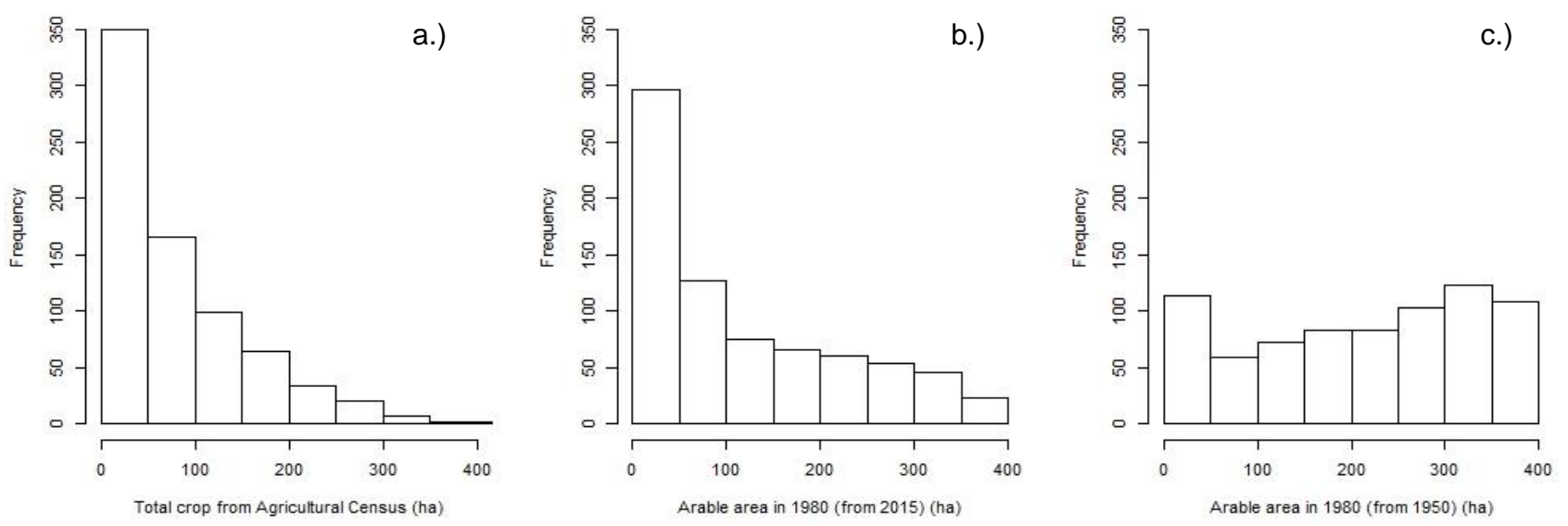

Fig. S1b Histograms showing the area of arable in Dorset in a.) 1981 from the Agricultural Census, b.) 1980 created from the Land Cover Map 2015 (Rowland et al., 2017a) and c.) 1980 created from the modelled 1950 map
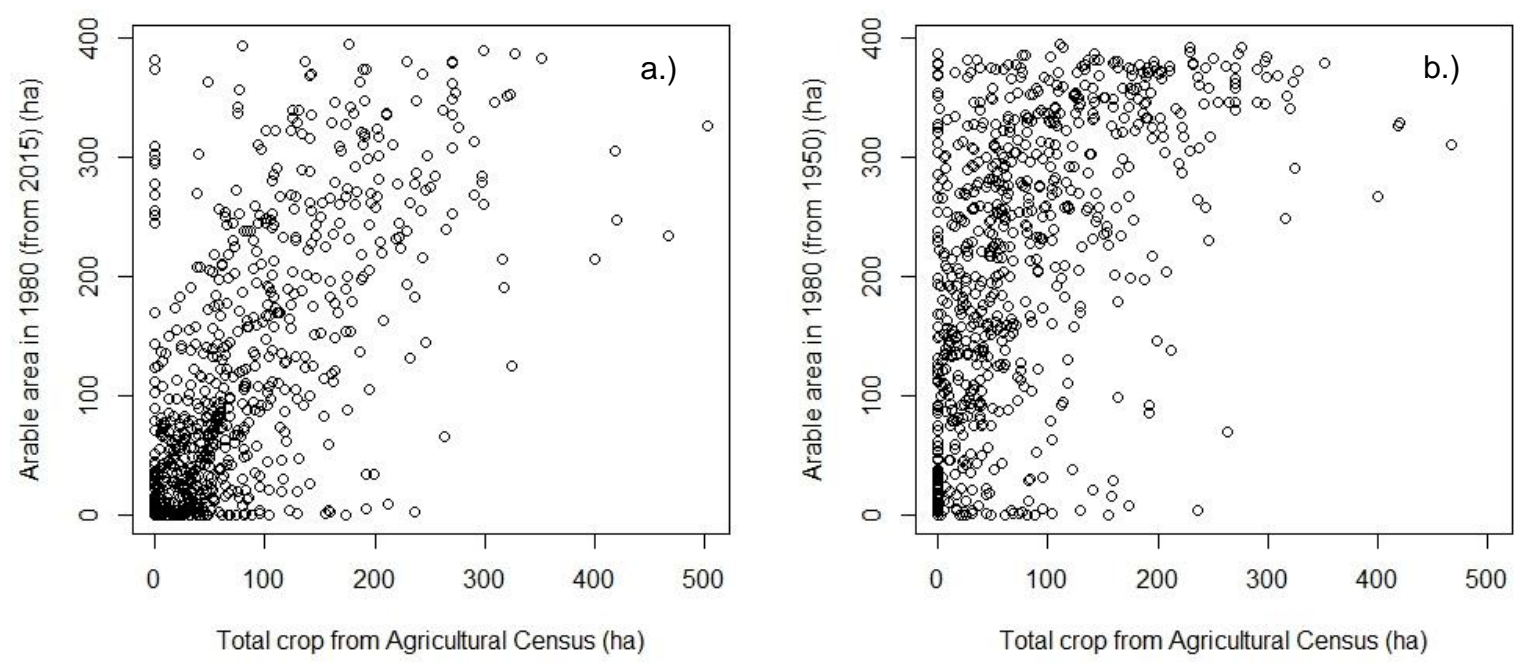

Fig. S1b Scatterplots showing the relationships between total crop in the Agricultural Census and arable in 1980 created from a.) the Land Cover Map 2015 (Rowland et al., 2017a) and b.) the modelled 1950 map 
Online Resource 2 Transition matrix required for the InVEST Scenario Generator Tool (Sharp et al., 2016). This example is for the first cross-validation dataset for the creation of the 1950 map.

\begin{tabular}{|c|c|c|c|c|c|c|c|c|c|c|c|c|c|c|c|c|c|}
\hline Id & Name & $\begin{array}{l}\dot{\bar{d}} \\
\dot{z}\end{array}$ & $\frac{\frac{0}{2}}{\frac{\pi}{2}}$ & $\begin{array}{l}\bar{\pi} \\
\stackrel{\Xi}{\Xi} \\
\overline{0} \\
Z\end{array}$ & 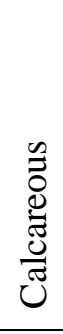 & $\frac{0}{2}$ & 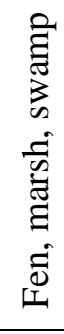 & 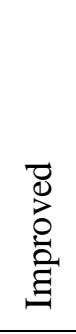 & 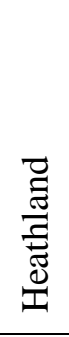 & $\begin{array}{l}\text { శే } \\
\tilde{\Xi} \\
\tilde{\Xi} \\
\tilde{U}\end{array}$ & 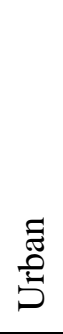 & 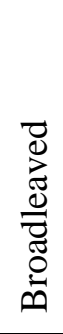 & 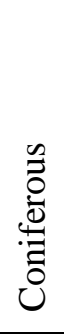 & $\begin{array}{l}\text { Percent } \\
\text { Change }\end{array}$ & $\begin{array}{l}\text { Area } \\
\text { Change }\end{array}$ & Priority & Proximity \\
\hline 1 & Water & 0 & 0 & 0 & 0 & 0 & 0 & 0 & 0 & 0 & 0 & 0 & 0 & 0 & 0 & 0 & 0 \\
\hline 2 & Arable & 0 & 0 & 0 & 0 & 0 & 0 & 0 & 0 & 0 & 0 & 0 & 0 & 122 & 0 & 8 & 1000 \\
\hline 3 & Neutral grassland & 0 & 9 & 0 & 0 & 0 & 0 & 9 & 0 & 0 & 4 & 4 & 0 & 0 & 0 & 0 & 0 \\
\hline 4 & Calcareous grassland & 0 & 9 & 0 & 0 & 0 & 0 & 9 & 0 & 0 & 4 & 4 & 6 & 0 & 0 & 0 & 0 \\
\hline 5 & Acid grassland & 0 & 0 & 0 & 0 & 0 & 0 & 8 & 0 & 0 & 0 & 0 & 0 & 0 & 0 & 0 & 0 \\
\hline 6 & Fen, marsh, swamp & 0 & 9 & 0 & 0 & 0 & 0 & 8 & 0 & 0 & 4 & 8 & 4 & 0 & 0 & 0 & 0 \\
\hline 7 & Improved grassland & 0 & 0 & 0 & 0 & 0 & 0 & 0 & 0 & 0 & 0 & 0 & 0 & 0 & 15100 & 7 & 0 \\
\hline 8 & Heathland & 0 & 5 & 0 & 0 & 0 & 0 & 8 & 0 & 0 & 4 & 4 & 8 & 0 & 0 & 0 & 0 \\
\hline 9 & Coastal & 0 & 0 & 0 & 0 & 0 & 0 & 8 & 0 & 0 & 0 & 0 & 0 & 0 & 0 & 0 & 0 \\
\hline 10 & Urban & 0 & 0 & 0 & 0 & 0 & 0 & 0 & 0 & 0 & 0 & 0 & 0 & 1 & 0 & 0 & 0 \\
\hline 11 & Broadleaved woodland & 0 & 6 & 0 & 0 & 0 & 0 & 7 & 0 & 0 & 0 & 0 & 6 & 0 & 0 & 0 & 0 \\
\hline 12 & Coniferous woodland & 0 & 0 & 0 & 0 & 0 & 0 & 0 & 0 & 0 & 0 & 0 & 0 & 1275 & 0 & 5 & 1000 \\
\hline
\end{tabular}


Online Resource 3 Transition matrix required for the InVEST Scenario Generator Tool (Sharp et al., 2016). This example is for the first cross-validation dataset for the creation of the 1980 map

\begin{tabular}{|c|c|c|c|c|c|c|c|c|c|c|c|c|c|c|c|c|c|c|}
\hline Id & Name & 离 & $\frac{\frac{0}{0}}{\frac{\pi}{2}}$ & 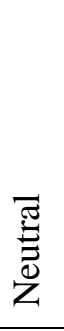 & 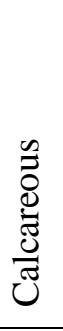 & $\frac{\overline{0}}{\pi}$ & 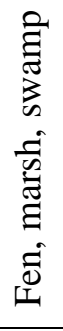 & 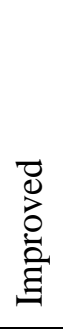 & 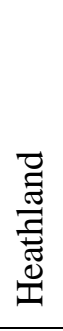 & 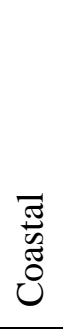 & 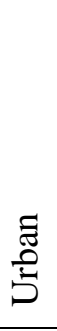 & 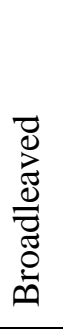 & 告 & $\stackrel{\grave{\Xi}}{\tilde{0}}$ & $\begin{array}{l}\text { Percent } \\
\text { Change }\end{array}$ & $\begin{array}{l}\text { Area } \\
\text { Change }\end{array}$ & Priority & Proximity \\
\hline 1 & Water & 0 & 0 & 0 & 0 & 0 & 0 & 0 & 0 & 0 & 0 & 0 & 0 & 0 & 0 & 0 & 0 & 0 \\
\hline 2 & Arable & 0 & 0 & 7 & 8 & 0 & 0 & 7 & 0 & 0 & 0 & 0 & 0 & 0 & 5 & 0 & 7 & 1000 \\
\hline 3 & Neutral grassland & 0 & 0 & 0 & 0 & 0 & 0 & 0 & 0 & 0 & 0 & 0 & 0 & 0 & 375 & 0 & 9 & 1000 \\
\hline 4 & Calcareous grassland & 0 & 0 & 0 & 0 & 0 & 0 & 0 & 0 & 0 & 0 & 0 & 0 & 0 & 33 & 0 & 9 & 1000 \\
\hline 5 & Acid grassland & 0 & 0 & 0 & 0 & 0 & 0 & 0 & 0 & 0 & 0 & 0 & 0 & 0 & 0 & 0 & 0 & 0 \\
\hline 6 & Fen, marsh, swamp & 0 & 0 & 0 & 0 & 0 & 0 & 0 & 6 & 6 & 0 & 0 & 0 & 0 & 62 & 0 & 9 & 1000 \\
\hline 7 & Improved grassland & 0 & 9 & 8 & 9 & 0 & 8 & 0 & 0 & 5 & 0 & 0 & 0 & 0 & 0 & 0 & 0 & 0 \\
\hline 8 & Heathland & 0 & 0 & 0 & 0 & 0 & 0 & 0 & 0 & 0 & 0 & 0 & 0 & 0 & 28 & 0 & 9 & 1000 \\
\hline 9 & Coastal & 0 & 0 & 0 & 0 & 0 & 0 & 0 & 0 & 0 & 0 & 0 & 0 & 0 & 16 & 0 & 7 & 1000 \\
\hline 10 & Urban & 0 & 0 & 0 & 0 & 0 & 0 & 0 & 7 & 0 & 0 & 0 & 0 & 0 & 0 & 0 & 0 & 0 \\
\hline 11 & Broadleaved woodland & 0 & 0 & 7 & 7 & 0 & 9 & 0 & 7 & 0 & 0 & 0 & 0 & 0 & 0 & 0 & 0 & 0 \\
\hline 12 & Coniferous woodland & 0 & 0 & 0 & 0 & 0 & 0 & 0 & 8 & 0 & 0 & 0 & 0 & 0 & 0 & 0 & 0 & 1000 \\
\hline 13 & Other & 0 & 0 & 0 & 0 & 0 & 0 & 0 & 0 & 0 & 0 & 0 & 0 & 0 & 0 & 0 & 0 & 0 \\
\hline
\end{tabular}


Page $\mathbf{3 3}$ of $\mathbf{3 3}$ 